\title{
Dedicated to
}

\section{Altab Ali}

Murdered in Whitechapel, in London's East End on 4 May 1978 by a group of white supremacists.

His death changed the British-Bangladeshi community forever. His memory will never die. 
Ali Riaz - 9781526111333

Downloaded from manchesterhive.com at $04 / 26 / 2023$ 07:10:36AM via free access 